\title{
Zakres uniformizacji ochrony wynagrodzenia za pracę $w$ umownych stosunkach zatrudnienia
}

Scope of protection's uniformity of remuneration for work
in labour and civil contractual employment relationships

\author{
dr Eliza Maniewska
}

Uniwersytet Warszawski, Wydział Prawa i Administracji,

Katedra Prawa Pracy i Polityki Społecznej

m.maniewska@wpia.uw.edu.pl

Streszczenie Artykuł zawiera ocenę zakresu ustawowej uniformizacji ochrony wynagrodzenia za pracę z ty tułu pozostawania $\mathrm{w}$ stosunku pracy oraz $\mathrm{z}$ tytułu pozostawia $\mathrm{w}$ cywilnoprawnym stosunku zatrudnienia (głównie na podstawie umowy o świadczenie usług). Ocena ta została dokonana przy uwzględnieniu zakre su i treści konstytucyjnej ochrony wynagrodzenia za pracę oraz dopuszczalności zróżnicowania i kryteriów dyferencjacji tej ochrony.

Słowa kluczowe: wynagrodzenie za pracę; ochrona wynagrodzenia za pracę, prawo zatrudnienia, umowa o dzieło, umowa agencyjna, umowa zlecenia (o świadczenie usług), wynagrodzenie minimalne, minimalna stawka godzinowa, wykładnia pojęć konstytucyjnych.

Summary The analyse evaluates statutory tendency to uniform the protection of remuneration for work resulting from labour and civil law employment relationships. The evaluation assesses constitutional requirements of such a protection as well as a right to differentiate it basing on certain criteria.

Keywords: remuneration for work, protection of the remuneration for work, employment law, a project contract, an agency contract, a mandate contract (services contract), minimal wage, minimal hourly wage, interpretation of constitutional terms.

JEL: K31

Str. 28-38

\section{Bibliografia}

Bień-Kacała, A. (2016). Zasada równości - orzeczenie z dnia 3 września 1996 r., K 10/96. W: M. Derlatka, L. Garlicki, M. Wiącek, Na straży państwa prawa. Trzydzieści lat orzecznictwa Trybunału Konstytucyjnego. Warszawa.

Czapliński, W. (2005). Glosa do wyroku TK z dnia 22 kwietnia 2005 r., P 1/05. Państwo i Prawo, (9).

Dobrowolski, M. (2005). Glosa do wyroku TK z dnia 12 stycznia 2005 r., K 24/04. Przegląd Sejmowy, (3).

Domańska, A. (2001). Zasady sprawiedliwości we wspótczesnym prawie konstytucyjnym. Łódź.

Garlicki, L. (2016). Komentarz do Rozdziału I Konstytucji. W: L. Garlicki, M. Zubik (red.), Konstytucja Rzeczypospolitej Polskiej. Komentarz. Tom I. Warszawa.

Garlicki, L. Zubik, M. (2016). Komentarz do art. 32 Konstytucji. W: L. Garlicki, M. Zubik (red.), Konstytucja Rzeczy pospolitej Polskiej. Komentarz. Tom II. Warszawa.

Gersdorf, M. (2013). Prawo zatrudnienia. Warszawa.

Gersdorf, M. Rączka, K. Maniewska, E. Raczkowski, M. (2018). Prawo pracy. Pytania i odpowiedzi. Warszawa.

Gierach, E. (2005). Glosa do wyroku TK z dnia 22 kwietnia 2005 r., P 1/05. Przegląd Sejmowy, (5).

Grajewski, K. (2006). Glosa do wyroku TK z 22 kwietnia 2005 r., P 1/05. Gdańskie Studia Prawnicze - Przegląd Orzecznictwa, (1). Grzebyk, P. (2016). Glosa do wyroku TK z 2 czerwca 2015 r., K 1/13. Przegląd Sądowy, (11). 
Hajn, Z. (2000). Glosa do wyroku SN z 16 grudnia 1998 r., II UKN 394/98. Orzecznictwo Sądów Polskich, (12).

Hofmański, P. (2005). Glosa do wyroku TK z dnia 22 kwietnia 2005 r., P 1/05. Państwo i Prawo, (9).

Jaśkowski, K. Maniewska, E. (2017). Minimalne wynagrodzenie w umowach zlecenia i o świadczenie usług. Praca $i$ Zabezpieczenie Spoleczne, (2).

Kapusta, P. (2016). Glosa do wyroku TK z 2 czerwca 2015 r., K 1/13. Przegląd Sejmowy, (5).

Kruszyński, P. (2005). Glosa do wyroku TK z dnia 22 kwietnia 2005 r., P 1/05. Palestra, (7-8).

Krzywoń, A. (2017). Konstytucyjna ochrona pracy i praw pracowniczych. Warszawa.

Latos-Miłkowska, M. (2019). Ochrona osób zatrudnionych na podstawie umów cywilnoprawnych w razie niewypłacalności pracodawcy. Praca i Zabezpieczenie Spoleczne, (1).

Leczykiewicz, D. (2006). Glosa do wyroku TK z dnia 22 kwietnia 2005 r., P 1/05. CML Review, (4).

Mik, C. Pawłowski, B. (2005). Glosa do wyroku TK z dnia 12 stycznia 2005 r., K 24/04. Przeglad Sejmowy, (3).

Musiała, A. (2015). Glosa do wyroku SN z 11 września 2013 r., II PK 372/12. Orzecznictwo Sądów Polskich, (1).

Musiała, A. (2016). Glosa do wyroku TK z 2 czerwca 2015 r., K 1/13. Gdańskie Studia Prawnicze — Przegląd Orzecznictwa, (1).

Piotrowski, R. (2016). Pojęcia zastane w Konstytucji RP. Dy lematy teorii i praktyki. W: T. Giaro (red.), Źródta prawa. Teoria $i$ praktyka. Warszawa.

Pisarczyk, Ł. (2008). Ryzyko pracodawcy. Warszawa.

Płachta, M. R. Wieruszewski, R. (2005). Glosa do wyroku TK z dnia 22 kwietnia 2005 r., P 1/05. Państwo i Prawo, (9).

Podgórska-Rakiel, E. (2017). Glosa do wyroku TK z 2 czerwca 2015 r., K 1/13. Gdańskie Studia Prawnicze — Przegląd Orzecznictwa, (3).

Pułło, A. (2003). Sprawiedliwość społeczna w systemie zasad naczelnych Konstytucji RP. Państwo i Prawo, (7).

Sanetra, W. (1971). Ryzyko osobowe zaktadu pracy. Warszawa.

Sanetra, W. (2009). Bodźcowa funkcja wynagrodzenia za pracę w warunkach społecznej gospodarki rynkowej. W: W. Sanetra (red.), Wynagrodzenie za pracę w warunkach społecznej gospodarki rynkowej. Warszawa.

Sobczyk, A. (2012). Wynagrodzenie minimalne zleceniobiorców. Praca i Zabezpieczenie Społeczne, (8).

Sobczyk, A. (2013). Prawo pracy w świetle Konstytucji RP. T. II. Warszawa.

Sokolewicz, W. (2016). Komentarz do art. 2 Konstytucji. W: L. Garlicki, M. Zubik (red.), Konstytucja Rzeczypospolitej Polskiej. Komentarz. Tom I. Warszawa.

Stawecki, T. (2014). Koncepcja autonomicznej wykładni pojęć konstytucyjnych: od praktyki do teorii. W: T. Stawecki, J. Winczorek (red.), Wykładnia Konstytucji. Inspiracje, teorie, argumenty. Warszawa.

Steinborn, S. (2005). Glosa do wyroku TK z dnia 22 kwietnia 2005 r., P 1/05. Przegląd Sejmowy, (5).

Szczerski, J. (1972). Komentarz do art. 737 k.c. W: J. Ignatowicz (red.), Kodeks cywilny. Komentarz, 2, Księga trzecia - zobowiązania. Warszawa.

Szymczak, M. (1979). W: M. Szymczak (red.), Stownik języka polskiego. Warszawa.

Szmyt, A. (2005). Glosa do wyroku TK z dnia 12 stycznia 2005 r., K 24/04. Gdańskie Studia Prawnicze — Przegląd Orzecznictwa, (4). 